TEACHING TACTIC

\title{
Seeing the Unseen: Art and Politics in the Biblical Studies Classroom
}

\author{
Sonja Anderson \\ Carleton College
}

\section{The context}

I created this exercise for an introductory religion course on "Jesus, the Bible, and Christian Beginnings" at a non-sectarian liberal arts college. The course enrolls twentyfive students and is discussion-based and writing-intensive. Students have read Mark, Luke, and select historical-critical, feminist, and liberationist biblical scholarship by the time we do this exercise.

\section{The pedagogical purpose}

Discussing the politics of biblical interpretation can be fraught for students whose religious commitments to the Bible may block them from developing the critical distance necessary for academic religious studies. This exercise uses visual analysis to bring politics-social arrangements of power based on gender, race, class, etc.-into the biblical text and into the classroom. It also shows students how much they can notice when they slow down, helps students review biblical texts already read, and sparks a discussion of hermeneutics and the ethics of interpretation.

\section{Description of the strategy}

I project Diego Velázquez's seventeenth-century painting Kitchen Maid with Supper at Emmaus. ${ }^{1}$ Students spend three minutes in silence looking at the painting. Most finish after just one minute, glance around the room, and sheepishly resume looking. They then spend two minutes writing down what they saw before turning to a neighbor and asking, "What did you see?" and, "What do you think this painting is depicting?"

Students share their answers with the class, and a consensus usually develops that the painting is of the Last Supper, with an unnamed dishwasher listening in. I then reveal its title and ask someone to read out the relevant passage: Luke 24:13-35. This text describes a resurrected Jesus whom the disciples meet on the road but don't recognize until he sits down and breaks bread with them-at which point he vanishes from their sight. Luke's story is about recognition and misrecognition, especially as mediated through sound and hearing, appearance and sight. Unlike Velázquez, Luke mentions no women (or skin color).

I ask students how the title-Supper at Emmaus versus Last Supperchanges their interpretation of the painting. Perhaps, as Poet Laureate Natasha Tretheway suggests, ${ }^{2}$ the kitchen maid isn't just eavesdropping but is actually recognizing a voice she's heard before, at the Last Supper, where she was also present but unseen by others (Tretheway, Thrall, 2012 Houghton Mifflin Harcourt). I ask students if they think this is a legitimate interpretive move. May one "read into" a text characters and viewpoints that are "not there"? How might historical critics, feminist critics, and liberation theologians answer?

\section{Why it is effective}

This exercise sidesteps students' religious commitments by analyzing an image rather than the Bible itself. Through visual analysis, students (including those whose reading skills are weaker) experience firsthand how meaning is produced. Through the juxtaposition of image and text, students see how little information a text actually conveys and how much must be supplied-consciously or unconsciously-by the reader.

1 https://www.nationalgallery.ie/art-and-artists/highlights-collection/kitchen-maid-supper-emmausdiego-velazquez-1599-1660.

2 https://poets.org/poem/kitchen-maid-supper-emmaus-or-mulata. 